Annals of Warsaw University of Life Sciences - SGGW

Land Reclamation No 41, 2009: 57-69

(Ann. Warsaw Univ. of Life Sci. - SGGW, Land Reclam. 41, 2009)

MAREK MADEYSKI $^{1}$, BOGUSŁAW MICHALEC ${ }^{2}$, MAREK TARNAWSKI ${ }^{3}$

${ }_{1,2,3}$ Department of Water Engineering, Agriculture University in Cracow

\title{
Flood threat to the territories below the water dam in conditions of occurrence of extreme hydrological phenomena
}

\begin{abstract}
Flood threat to the territories below the water dam in conditions of occurrence of extreme hydrological phenomena. The course of the flood in July 2001 and passage of the freshet wave through the water reservoir Chańcza on the Czarna Staszowska River was analyzed. Culmination of this wave equaling $418.62 \mathrm{~m}^{3} \cdot \mathrm{s}^{-1}$ was two times higher than the estimated flow of $1 \%$ probability for what the reservoir was designed. Water management during the flood forced a higher than forecast water discharge during culmination. The paper aims at determination of water level situation on the territory at maximum water discharge from the reservoir during the flood equaling $122.75 \mathrm{~m}^{3} \cdot \mathrm{s}^{-1}$ and showing possibilities of flood threat reduction. The range of the inundation zone at this discharge flow on the territory below the dam at the length of $3 \mathrm{~km}$ was determined taking into regard the influence of vegetation in the valley and in the zone adjacent the channel and bridge. The cause of inundation of the valley on the studied river sector is a rather low channel capacity equaling from $20-60 \mathrm{~m}^{3} \cdot \mathrm{s}^{-1}$. It was found that the bridge does not influence the leveling of the analyzed flow and the reserve in the bridge light, determined as the difference of ordinate of the underlay of the span beam and ordinate of the water level under the bridge 0.92 $\mathrm{m}$. Calculations of the channel capacity were also carried out in the case of renovation treatments consisting in removing stiff and soft vegetation and decrease in the inundation range of the valley was demonstrated.
\end{abstract}

Key words: reservoir, flood waves, water dam, flood threat.

\section{INTRODUCTION}

Improvement of water resources availability is possible by water amassing and its utilization at a proper time. Each retention reservoir, independent of its aims and functions it servers, is an object which may significantly influence qualitativeandquantitativecharacteristics of its resources adapting them to the needs of their users and consumers at observation of requirements of ecology and water environment. Retention reservoirs are typical reservoirs of Carpathian conditions; they usually play simultaneously the role of a conservation storage reservoir consisting in storing water for drinking and industrial purposes for electric power and flood protection. This is connected with reduction of flood wave culmination and protection of territories below the reservoir as well as with recreation (Mikulski 1998). Significant meaning for flood protection efficiency of function of each water reservoir is conditioned by proper water management during passage of extreme flood wave Floods are defined as very large amounts of water coming in very short time; these in particular regions are 
caused mainly by intensive rainfalls or melting snow. Therefore relation between safe management of water reservoir and effective weakening of flood is the main element in every analysis of controlled river system (Cederwall 2005). The way of freshet wave reduction dependent on proper water management of the reservoir, schedule of discharge equipment service, where the capacity of the channel and hydrotechnical objects as well as bridges below the reservoir are considered is very important.

On 25 July 2001 there occurred a freshet wave in the upper part of the basin of the Czarna Staszowska River. It was caused by intensive rain and the inflow to the Reservoir Chańcza (the Reservoir Chańcza is located at $32+000 \mathrm{~km}$ of this river) had its culmination value 419 $\mathrm{m}^{3} \cdot \mathrm{s}^{-1}$. The value of this culmination was almost twice as big as the estimated flow of probability of $1 \%$ for that the reservoir was designed. The determined time of culmination exceeding $15 \mathrm{~m}^{3} \cdot \mathrm{s}^{-1}$ lasted over 60 hours. As it was published by Rodrigues et al. (2002) in appraise of flood threat determination of culmination time lapse of the freshet wave inflowing into the reservoir is essential. In this appraise it is essential to determine the depth in the inundation valley and hydraulic parameters among others average flow velocity, width of the water level (Rodrigues et al. 2002).

In the paper situation of water level on the territory below the water dam at maximum water discharge from the reservoir during flood equaling 122.75 $\mathrm{m}^{3} \cdot \mathrm{s}^{-1}$ was determined and possibilities of flood threat reduction were shown. The range of the flooding zone at this discharge flow on the territory below the dam on the length of $3,0 \mathrm{~km}$ was determined taking into consideration the influence of vegetation in the valley and in the channel adjacent the zone and bridge. The cause of the valley inundation on the examined river section is a small capacity of the river bed being only $20-60 \mathrm{~m}^{3} \cdot \mathrm{s}^{-1}$. In result of the carried out calculations of capacity of the Czarna Staszowska channel, considering the variant of renovation treatments, soft vegetation reduction of inundation range of valley was demonstrated.

\section{MATERIAL AND METHODS}

The Czarna Staszowska River flows across the south-eastern part of the Świętokrzyski District and is a left bank tributary of the River Wisła, of the length $61 \mathrm{~km}$ with its estuary at $222 \mathrm{~km}$ of the River course Wisła (Fig. 1). The surface area of the basin is $1354 \mathrm{~km}^{2}$ and according to geographic classification (Kondracki 1998) belongs to the territory of Little Poland Upland. It includes the southern part of the Kielecka Upland including mezoregions: the Świętokrzyskie Mts and the Szydłowskie Plateau as well as eastern fragments of the syncline of the Nadwiślański Lowland included into the macroregion of the Sandomierska Syncline. The springs of the Czarna Staszowska River are on the south eastern border of the Świętokrzyskie Mts in the marshes Białe Lugi in the Cisowski belt. Watermeter posts of IMGW are in Raków, Staszów and Połaniec. On the Czarna Staszowska River at its $40+300$ $\mathrm{km}$ between Raków and Korytnica there was built in the 1974-1984 a water dam reservoir in the region of the locality 


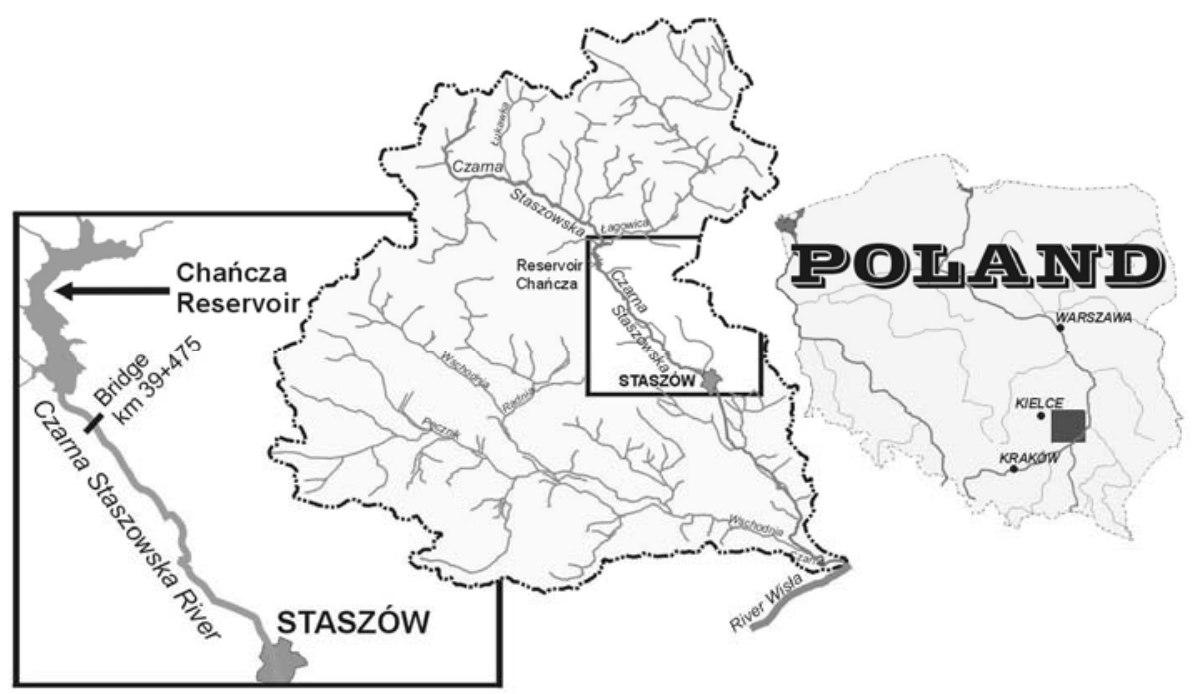

FIGURE 1. Catchment area of Czarna Staszowska River

Chańcza. The water Reservoir Chańcza closes the basin of $475 \mathrm{~km}^{2}$ area and its aim is reducing flood wave, water supply for the town Staszów, maintenance of biological flow in the river channel below the reservoir and to create conditions for recreation.

Instruction of water management in the Reservoir Chańcza (Cabala 2001) presents a scheme of water discharge from the reservoir by means of discharge equipments. She proposes a consequent including of particular passages of bottom dischargers in dependence on water level and quantity of inflowing water. At inflow $15 \mathrm{~m}^{3} \cdot \mathrm{s}^{-1}$ the outflow is $15 \mathrm{~m}^{3} \cdot \mathrm{s}^{-1}$. Opening of one passage of the bottom dischargers takes place when the inflow increases above $32.5 \mathrm{~m}^{3} \cdot \mathrm{s}^{-1}$ and the level $218.00 \mathrm{~m}$ a.s.l. is exceeded. At the moment the crest of the weir $218.60 \mathrm{~m}$ a.s.1. is exceeded, automatic reduction by surface overflow starts. Consequent passages of the bottom discharger switch in exceeding determined limits of water levels in the reservoir. The appraised by Cabala (2001) culmination of water inflow into the reservoir during the flood in July 2001 was $419 \mathrm{~m}^{3} \cdot \mathrm{s}^{-1}$. It was a flow of occurrence probability below $0.01 \%$. Culmination of this wave exceeded the quantities of control water flow equaling $342 \mathrm{~m}^{3} \cdot \mathrm{s}^{-1}$ and reliable water flow equaling $278 \mathrm{~m}^{3} \cdot \mathrm{s}^{-1}$, assumed during designing of the reservoir. Water management during the flood under discussion permitted to reduce the maximum discharge to $114.5 \mathrm{~m}^{3} \cdot \mathrm{s}^{-1}$ what constituted $72,6 \%$ of wave reduction.

The flood wave occurred on 24.07.2001 during evening hours about 9 p.m. when the inflow into the reservoir increased from $56 \mathrm{~m}^{3} \cdot \mathrm{s}^{-1}$. The recorded flow on 25.07.2001 at midnight was 418 $\mathrm{m}^{3} \cdot \mathrm{s}^{-1}$. In these unusual conditions a decision was undertaken to open three of the six bottom dischargers $\varnothing 1400$ what caused water outflow in the quantity of $62 \mathrm{~m}^{3} \cdot \mathrm{s}^{-1}$. After half an hour other two bottom dischargers were opened and 
together with the already acting surface overflow caused the discharge of 122.75 $\mathrm{m}^{3} \cdot \mathrm{s}^{-1}$. Such as water discharge was maintained till 6.20 a.m. of the same day when closing of one discharger was decided and then the outflow was reduced to $87.1 \mathrm{~m}^{3} \cdot \mathrm{s}^{-1}$. On 26.07 .2001 at 4.00 a.m. after a time lapse of 22 hours a consequent discharger was closed and the outflow decreased to the value of $62.18 \mathrm{~m}^{3} \cdot \mathrm{s}^{-1}$. After other 4 hours i.e. at $8.00 \mathrm{a} . \mathrm{m}$. the water was discharged from the reservoir by use of only one discharger whose output was $20.73 \mathrm{~m}^{3} \cdot \mathrm{s}^{-1}$. This water discharge was maintained till 27.07.2001 till 5.00 a.m. (Madeyski 2006). The consequences of such quantities of discharged water and effect of outflow from the river bed below the reservoir as well as possibility of flow under bridges is the aim of the undertaken analysis.

The evaluation of flood threat of the territories below the water dam Reservoir Chańcza included the river bed sector Czarna Staszowska of the length $3.3 \mathrm{~km}$ i.e. from $40+300$ to $37+000$. The initial sector of the channel below the lower level of overflows and dischargers of the dam of the length $400 \mathrm{~m}$ is trained. The further part is constituted by a channel of diversified geometry and intensive biological development on channel slopes and in the zone close to it. Within the framework of territory investigations geodetic survey of the longitudinal slope of the bottom of the Czarna Staszowska River, determined eight cross-sections of the valley and river channel was carried out. A survey check list of vegetation cover in the river bed and territory of the valley was also performed in appointed cross-sections of the analyzed sector.

Geodetic survey of the bridge located at the $39+475 \mathrm{~km}$ and cross-section bellow and above the bridge were made in order to calculate its capacity; this was made in agreement with the regulation of Ministerstwo Transportu i Gospodarki Wodnej (Rozporządzenie 2000). The elevation height in the light of the bridge for the maximum discharge flow equaling $122.75 \mathrm{~m}^{3} \cdot \mathrm{s}^{-1}$ was calculated. The so called reserve in the light of the bridge, being the difference between the level of the lower edge of the bridge span beam and water level elevated by the bridge was established. Evaluation caused by the bridge causes a raise of the water level in the channel above the bridge. The obtained calculation results are the appraise basis of the bridge influence on the change of water level under the bridge and section above it. In the analysis of bridge capacity this state of natural biological development of the river above and below the bridges (variant A) was considered. Subsequently calculations of bridge capacity were performed taking into consideration influence of change of the biological development state of the river by proposing improvement treatments of the channel and bank adjacent territories on capacity condition of the bridges (variant B). In variant B removal of bushes and vegetation characterized by Manning's coefficient " $\mathrm{n}$ " equaling 0.075 leaving only bushes $(\mathrm{n}=0.035)$, removal of rare trees and overgrowth $(n=0.10)$ leaving only willows $(n=0.06)$ was considered. On channel and river slopes and flood 
territory the coefficient of roughness will change gaining the value 0.05 due to trees and overgrowth $(\mathrm{n}=0.15)$ removal and leaving a cleaned ground area. Also in consequence of felling bushes and removal of soft vegetation decrease in coefficient " $n$ " from the value 0.05 to 0.035 was obtained. With regard to the reliable water level system and calculated flow $122.75 \mathrm{~m}^{3} \cdot \mathrm{s}^{-1}$ the bridge at $\mathrm{km} 39+475$ was classified to high water bridges characterized by a quiet water flow under the bridge. Calculation of elevation height $\left(\mathrm{h}_{1}{ }^{*}\right)$ was performed according to the method based on the principle of mechanical energy conservation (Kubrak, Nachlik 2003) according to the formula:

$\mathrm{h}_{1}^{*}=\mathrm{K} \cdot \alpha_{\mathrm{m}} \cdot \frac{\mathrm{V}_{\mathrm{m}}^{2}}{2 \mathrm{~g}}+\alpha_{1} \cdot\left[\left(\frac{\mathrm{A}_{\mathrm{m}}}{\mathrm{A}_{2}}\right)^{2}-\left(\frac{\mathrm{A}_{\mathrm{m}}}{\mathrm{A}_{1}}\right)^{2}\right] \cdot \frac{\mathrm{V}_{\mathrm{m}}^{2}}{2 \mathrm{~g}}$

where:

$\mathrm{K}$ - coefficient of energy losses, $\mathrm{V}_{\mathrm{m}}$ - mean flow velocity in the bridge section,

$A_{m}$ - cross-section surface area in the light of the bridge,

$\mathrm{A}_{1}$ - cross-section surface area above the bridge,

$\mathrm{A}_{2}-$ cross-section surface area below the bridge, $\mathrm{g}$ - acceleration of gravity,

$\alpha_{m}-$ St. Venant's coefficient for the bridge section,

$\alpha_{1}-$ St. Venant's coefficient for channel before the bridge; in the case of narrow bridge.

$\alpha_{1}=1.2$, and when the section is profiled it is determined from the formula:

$$
\alpha_{1}=1,1 \cdot \frac{\Sigma\left(\mathrm{v}_{1 \mathrm{i}}^{2} \mathrm{Q}_{\mathrm{i}}\right)}{\mathrm{v}_{1}^{2} \mathrm{Q}}
$$

where:

$\mathrm{v}_{1 \mathrm{i}}, \mathrm{Q}_{\mathrm{i}}$ - partial values of flow velocity and intensity referred to partial sections of the surface of a compact character, $\mathrm{Q}$ - total flow for which the elevation is calculated.

$\alpha_{m}-$ St. Venant's coefficient for under bridge section:

$$
\alpha_{\mathrm{m}}=1+\mathrm{M}\left(\alpha_{1}-1\right)
$$

$M$ - coefficient of contraction:

$\mathrm{M}=\frac{\mathrm{Q}_{\mathrm{b}}}{\mathrm{Q}}$

$\mathrm{Q}_{\mathrm{b}}$ - part of flow intensity which in the not walled up channel is of the width corresponding to the bridge light.

Coefficient of energy losses $(\mathrm{K})$ is calculated according to Rozporządzenie Ministra Transportu i Gospodarki Morskiej (2000), from the formula:

$\mathrm{K}=\mathrm{K}_{0}+\Delta \mathrm{K}_{\mathrm{f}}+\Delta \mathrm{K}_{\mathrm{e}}+\Delta \mathrm{K}_{\mathrm{p}}$

where:

$\mathrm{K}_{0}$ - basic coefficient of losses depended on coefficient of contraction $\mathrm{M}$,

$\Delta \mathrm{K}_{\mathrm{f}}$ - correction considering influence of piers,

$\Delta \mathrm{K}_{\mathrm{e}}$ - correction considering influence of asymetric location of the bridge light related to flood territories,

$\Delta \mathrm{K}_{\mathrm{p}}$ - correction considering influence of slant location of the bridge in relation to the river axis. If the angle measured between the longitudinal axis in the light is less than $45^{\circ}$ it is not considered in the correction $\Delta \mathrm{K}_{\mathrm{p}}$ as given in Instruction "HEC-RAS, Hydraulic Reference Manual" (HEC-RAS 1997).

Revision of calculation correctness of the formula (1), advised by Rozporządzenie Ministra Transportu 
i Gospodarki Morskiej (2000), was carried out according to the formula:

$$
\Delta \mathrm{z}=\mathrm{K} \cdot \frac{\alpha_{m} \cdot \mathrm{V}_{\mathrm{m}}^{2}}{2 \mathrm{~g}}+\frac{\alpha_{1} \cdot\left(\mathrm{V}_{2}^{2}-\mathrm{V}_{1}^{2}\right)}{2 \mathrm{~g}}
$$

where:

$\mathrm{V}_{1}$ - mean flow velocity in cross-section above the bridge after elevation,

$\mathrm{V}_{2}$ - mean flow velocity in cross-section below the bridge,

other denotation as in formula (1).

Elevation before the bridge should be determined by use of the iteration method considering the change of water flow velocity in consequence of elevation (Rozporządzenie Ministra Transportu i Gospodarki Morskiej 2000, HEC-RasSim 2003).

In the first approximation the estimated of elevation before the bridge modifies the surface area of the crosssection above the bridge and water depth reducing simultaneously the value of flow velocity. Elevation after occurrence of scour is calculated scour of the bottom of the bridge light.

Water level in the river bed of the Czarna Staszowska River and flood territory in appointed cross-sections I ( km 40+190), II (km 39+760), III (39+485), IV ( $\mathrm{km} 39+470), \mathrm{V}(\mathrm{km} 39+260), \mathrm{VI}(\mathrm{km}$ $38+320)$, VII $(\mathrm{km} \mathrm{37+840)}$ and VIII $(\mathrm{km}$ $37+000)$ was calculated for the analyzed flow $122.75 \mathrm{~m}^{3} \cdot \mathrm{s}^{-1}$. Calculations were carried out in two variants: Variant A corresponding to the existing state i.e. when the channel and its bank as well as the adjacent territory are in natural state and Variant B corresponding to the state after the proposed possibility of the channel maintaining natural shapes.
Hydraulic calculation of channel water level and determination of flow curves in cross-section in the Czarna Staszowska River were performed basing upon Chézy formula in which the coefficient of velocity was calculated according to the Manning's formula. On the basis of territory studies, the coefficient of roughness considering versification of mineral material present in the river bottom as well as diversification of vegetation on the banks and nearby territories was established (Michalec, Tarnawski 2006).

Calculations of flow and water level in cross-sections were performed by use of a computer program "cieq v.2.9" realized in the Microsoft Visual Basic for Application.

\section{RESULTS AND DISCUSSION}

In the first stage of calculation capacity of the Czarna Staszowska River was determined in two adopted variants. From the water reservoir section 1 at $40+190$ $\mathrm{km}$ the calculated slope of the channel bottom was $2.2 \%$. The embankment and river bed training on this sector may carry flows of about $300 \mathrm{~m}^{3} \cdot \mathrm{s}^{-1}$. The channel capacity on this sector from section I to section II is considerably lower equaling $140 \mathrm{~m}^{3} \cdot \mathrm{s}^{-1}$ (variant A). In result of renovation treatments capacity may be increased to $154 \mathrm{~m}^{3} \cdot \mathrm{s}^{-1}$ (variant B). The obtained results indicate that the channel is possible to transport a discharge flow of $122.75 \mathrm{~m}^{3} \cdot \mathrm{s}^{-1}$. From section II to the bridge section at $\mathrm{km} 39+475$ the flow in the channel at the existing state (variant A) is only $26.06 \mathrm{~m}^{3} \cdot \mathrm{s}^{-1}$. The bottom slope of this sector equals $7.7 \%$. The 
low capacity of this river sector is due to a bad state of the channel. Both banks of this sector are overgrown with trees and bushes and barriers formed by tree trunks and branches are formed. In case of making the channel passable (variant B) it means cutting trees and bushes and removal of barriers of wooden obstacles the capability in narrow river bed will increase to $29.58 \mathrm{~m}^{3} \cdot \mathrm{s}^{-1}$. In this sector the discharge flow which has no room in the channel will inundate the territories adjoining the banks. The river bed below the bridge to section $\mathrm{V}(\mathrm{km} \mathrm{38+320)}$ is characterized by capacity of 52.7-62.8 $\mathrm{m}^{3} \cdot \mathrm{s}^{-1}$. In result of calculations according to variant $\mathrm{B}$, the channel capacity may by increased to $90.5-103.2 \mathrm{~m}^{3} \cdot \mathrm{s}^{-1}$. An exceptional capacity is found in the channel in the section from section $\mathrm{V}$ to section VIII. The river bottom slope in this section is $0.76 \%$ and the channel may carry flows equaling only 12.0 $-17.0 \mathrm{~m}^{3} \cdot \mathrm{s}^{-1}$. After making is passable (variant B) capacity may by increased to $38.0-40.0 \mathrm{~m}^{3} \cdot \mathrm{s}^{-1}$. The obtained results of channel capacity calculations in sector below the bridge i.e. from the bridge section to section VIII at $37+000$ indicate to flooding threat to the valley.
Calculations of hydraulic parameters at discharge flow in valley sections were performed for the sector from the bridge section $(\mathrm{km} \mathrm{39+475)}$ to section VIII (km 37+000). The discharged water in conditions of natural biological development of the channel and inundation territories stepping out of the channel will cause inundation of the valley. Basic hydraulic parameters determined form section IV-VIII in variant $\mathrm{A}$ are given in table 1.

In the case of undertaking treatments aiming at making the channel passable by removing barriers formed by wooden debris, soft and stiff vegetation from the channel slopes and parts adjoining the inundation territories average lowering of the water surface level of the discharge flow equal 0.4 was obtained.

In result of geodetic surveys parameters of the bridge at $\mathrm{km} 39+475$ (Fig. 2) were determined. This is a two span bridge each span $5.8 \mathrm{~m}$ width and $4.92 \mathrm{~m}$ height. The spans are divided by two piers located in one plane perpendicular to the axis of the bridge road-way. The piers of rounded heads are $0.5 \mathrm{~m}$ wide.

TABLE 1. Basic hydraulic parameters determined for section IV-VIII - flow $122.75 \mathrm{~m}^{3} \cdot \mathrm{s}^{-1}$ (variant A)

\begin{tabular}{|l|c|c|c|c|c|}
\hline Cross-section & $\begin{array}{c}\text { Water depth } \\
\text { in river } \\
\mathrm{h}_{\max }[\mathrm{m}]\end{array}$ & $\begin{array}{c}\text { Water level } \\
\text { coordinate } \\
\text { [m a. s. 1.] }\end{array}$ & $\begin{array}{c}\text { Mean water } \\
\text { depth in the } \\
\text { flood zone of } \\
\text { the valley } \\
\mathrm{h}_{\text {sr }}[\mathrm{m}]\end{array}$ & $\begin{array}{c}\text { Cross-section } \\
\text { surface area } \\
\mathrm{F}\left[\mathrm{m}^{2}\right]\end{array}$ & $\begin{array}{c}\text { The water } \\
\text { width in } \\
\text { cross-section } \\
\text { of valley flood } \\
\text { zone of the } \\
\mathrm{b}[\mathrm{m}]\end{array}$ \\
\hline IV $(\mathrm{km} \mathrm{39+470)}$ & 3.55 & 205.75 & 0.34 & 82.73 & 136 \\
\hline V $(\mathrm{km} \mathrm{39+260)}$ & 3.48 & 205.51 & 0.63 & 114.30 & 242 \\
\hline VI $(\mathrm{km} \mathrm{38+320)}$ & 3.15 & 205.29 & 0.55 & 211.50 & 360 \\
\hline VII $(\mathrm{km} \mathrm{37+840)}$ & 3.75 & 205.03 & 0.46 & 240.96 & 459 \\
\hline VIII $(\mathrm{km} \mathrm{37+000)}$ & 3.12 & 204.95 & 0.94 & 230.30 & 445 \\
\hline
\end{tabular}




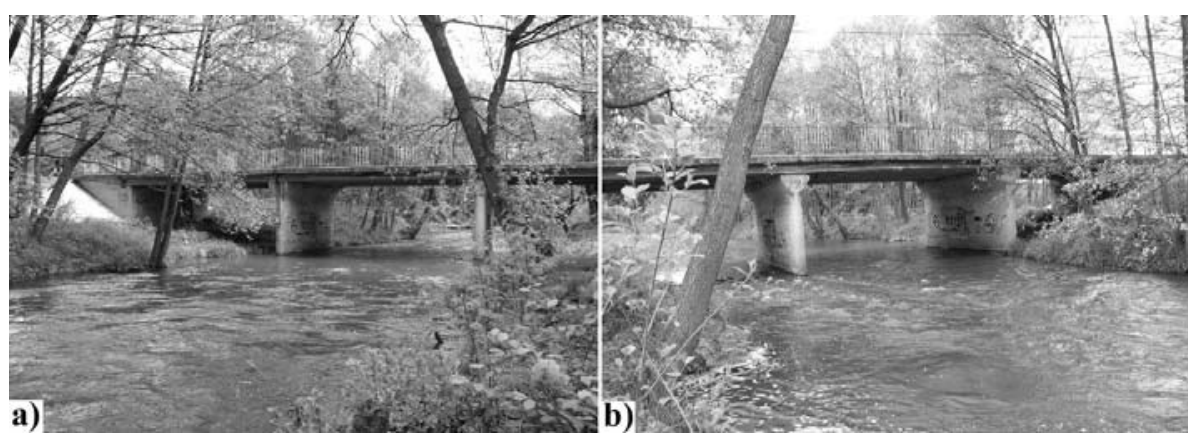

FIGURE 2. Photo of the bridge at km 39+475 on the Czarna Staszowska River; a) view from upstream, b) view from downstream

With regard to the perpendicular situation of the bridge related to the longitudinal axis of the Czarna Staszowska River, correction $\Delta \mathrm{K}_{\mathrm{e}}$ (HEC-RAS 1997) was not considered in calculations. Calculation results of elevation of discharge flow from the reservoir for variant A, B depth (h) and reserve $(\mathrm{Z})$ in the bridge light are presented in Table 2.

Calculation results at elevation height of flows $\mathrm{Q}=20.0 \mathrm{~m}^{3} \cdot \mathrm{s}^{-1}$ and $\mathrm{Q}=49.0 \mathrm{~m}^{3} \cdot \mathrm{s}^{-1}$ are given in Table 2 . The flow equaling $20.0 \mathrm{~m}^{3} \cdot \mathrm{s}^{-1}$ according to "Badania..." (1995) finds place in the river channel without any conservation treatments. Whereas the flow equal $49.0 \mathrm{~m}^{3} \cdot \mathrm{s}^{-1}$ according to the elaboration "Obliczenie wartości przepływów..." (2002) is a flow of probability $p=1 \%$. taking into consideration the economy carried out on the reservoir in agreement with principles in the instruction on dam water economy. With regard to the existing hydraulic conditions resulting from bridge structure characterized by big bridge light, high located span beam, flows $\mathrm{Q}=20.0 \mathrm{~m}^{3} \cdot \mathrm{s}^{-1}$ and $\mathrm{Q}=$ $=49.0 \mathrm{~m}^{3} \cdot \mathrm{s}^{-1}$ will not undergo elevation caused by the bridge. The discharge flow in the existing conditions (variant A) will be elevated to the height $0.06 \mathrm{~m}$. In result of renovation treatment of the channel and bank adjacent territories (variant B) the elevation height will decrease to $0.04 \mathrm{~m}$. As it results from the data presented in Table 2 execution of treatments making the channel passable exerts little influence on the conditions of freshet wave flow. The reserve in bridge light is in both variants over $2.0 \mathrm{~m}$.

The range of the flood zone of the valley of the Czarna Staszowska River in the examined sector in conditions of freshet water discharge was presented in blue colour in Figure 3. Maximal elevations determined in variant $\mathrm{A}$ are from $2.35 \mathrm{~m}$ (section I) to $3.75 \mathrm{~m}$. The mean depth on flood territories is within the range $0.34-0.94 \mathrm{~m}$. In consequence of making the channel passable and removal of a part of vegetation in bank adjoining zone the water level of the being inundated valley will be lowered on the average by $0.41 \mathrm{~m}$.

\section{CONCLUSIONS}

The channel of the Czarna Staszowska River from the river dam Chańcza to section I at $\mathrm{km} 39+760$ is characterized 


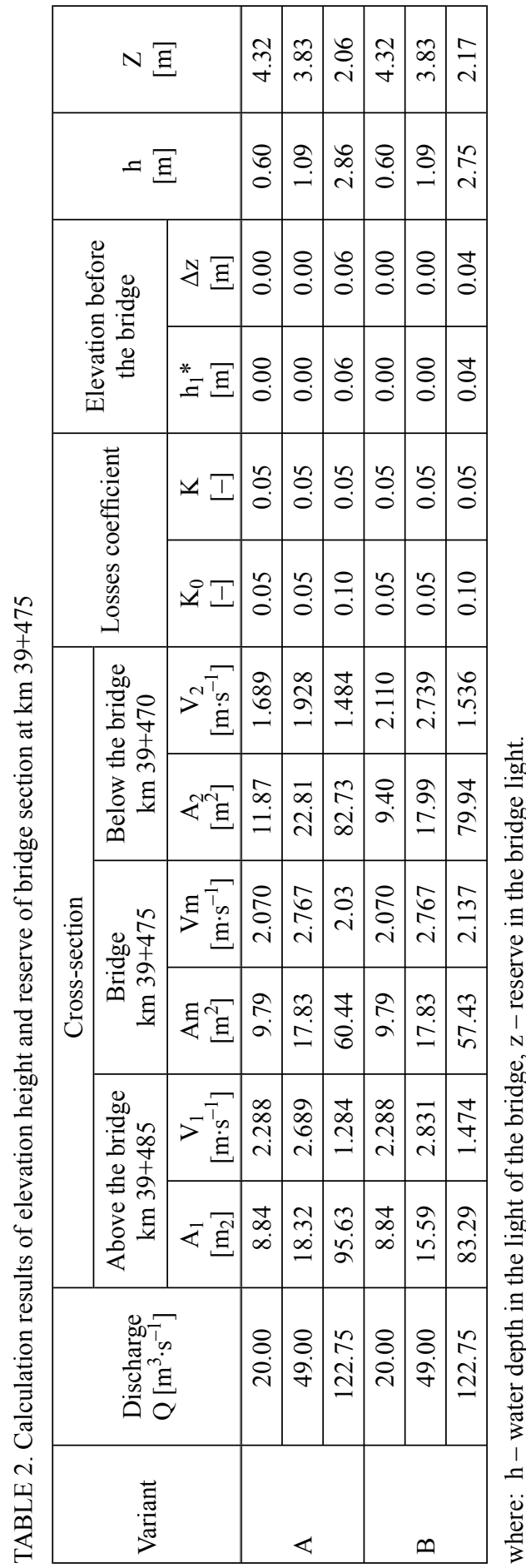

by high capacity. Discharged water from the reservoir equaling $122.75 \mathrm{~m}^{3} \cdot \mathrm{s}^{-1}$, flows in its river channel and will not step out of the banks and will not inundate the neighbouring adjoing territories. In the sector from section II to the bridge at $\mathrm{km} \mathrm{39+475} \mathrm{low} \mathrm{capacity} \mathrm{of} \mathrm{the} \mathrm{channel}$ in the existing conditions equaling only $26.0 \mathrm{~m}^{3} \cdot \mathrm{s}^{-1}$ will contribute to stepping out from the river channel and inundating the territory above the bridge.

The structural solutions of the bridge do not influence, in any significant way, the conditions of discharge water flow. In spite of considerable reserve in the bridge, over 2 meters there exists a risk of formation under the bridge of barriers formed of wooden debris. Steep banks of the river bed at a section above the bridge, covered with trees may be undercut during freshets. Trees, branches etc. form a barrier in the light of the bridge and cause a decrease in crosssection caused by formation of barriers as given by Mutz (2003), causes increase in water flow velocity, change of current direction, and increase in flow resistance, what influences in consequence bottom erosion intensity in the region of the bridge.

A much greater flood treat occurs on territories located below the bridge. A low channel capacity of only $12.0-17.0$ $\mathrm{m}^{3} \cdot \mathrm{s}^{-1}$ will cause inundation of the whole valley of the Czarna Staszowska River.

The obtained results of the channel capacity are lower then the flow equaling $20.0 \mathrm{~m}^{3} \cdot \mathrm{s}^{-1}$ which to according "Badania ..." (1995) should find place in the river channel without any renovation activities. Execution of these treatments in the river channel may only improve flow conditions of low and medium water 


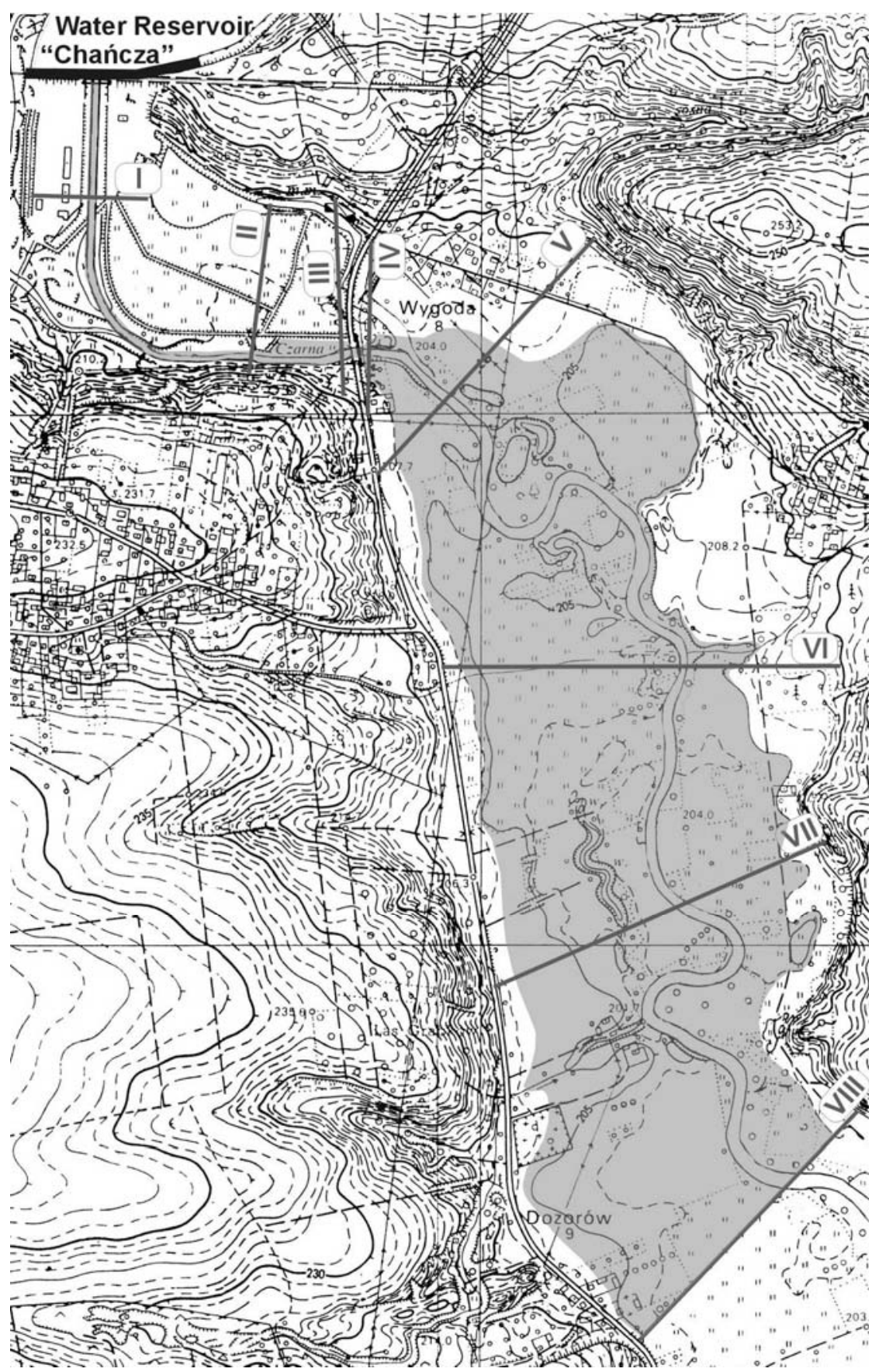

FIGURE 3. Range of the inundation zone in the valley of the Czarna Staszowska River in the sector from $\mathrm{km} 40+300$ (section of the reservoir dam Chańcza) to $\mathrm{km} \mathrm{37+000} \mathrm{(section} \mathrm{VIII)} \mathrm{in} \mathrm{conditions} \mathrm{of}$ freshet water discharge 
flows but in the case of freshet flows flooding of the valley will take place.

The hydraulic situation which prevailed during freshets on 24-26 July 2001 caused inundation of the Czarna Staszowska River. The discharge water level reached the level of the asphalt road leading to the right bank part of the valley and caused inundation of the cemetery and buildings of two farms on the right bank territory between sections VII and VIII. The width of the water level exceeded $450 \mathrm{~m}$.

Determination of time and freshet elevation constitute the basis for flood threat evaluation (Rodrigues et al. 2002). The elaborated analysis of inundation reach of the valley together with the available data describing the course of freshet culmination may be the basis for elaboration of conception of the valley protection. Flooding of the valley in the examined sector and bellow it on the whole length of the river to the town Staszów was not caused by improper management of stored water and discharged from reservoir during the flood. Water management in the reservoir carried during the flood in 2001 caused a reduction of the culmination wave by $72.6 \%$. The principal cause of flood threat is a too low capacity of the channel of Czarna Staszowska River, in spite of interventions and instructions of the Regional Authorities of Water Management in Cracow it was not subjected to the advised treatments making the channel passable and the flood territories and building objects are not protected by any system of proper anti-flood protections. Improvement of capacity of the Czarna Staszowska River consisting in execution of renovation, modernization works including possibility of the channel preserving the existing river bends and geometry of channel sections as well as by removing barriers formed by wooden debris, cutting off the vegetation of the channel and adjacent territory are in disagreement with the plans of subjecting the Czarna Staszowska River under protection within the framework of the program "Natura 2000". Therefore improvement of river bed flow capacity may not be realized in spite of increase of flood threat to territories below the dam. Losses suffered in result of flood were over $20 \mathrm{mln} \mathrm{zł}$. As given by Kron (2002) the top position in economical losses is attributed to flood losses. In Kron's analysis of costs connected with flood losses and costs of removing flood effects from the decade 1992-2002, Poland together with Czech Republic and Germany occupy the 13th place in the world.

\section{REFERENCES}

Badania dotyczące udrożnienia koryta rzeki Czarnej Staszowskiej [Conveyance investigations of channel of the Czarna Staszowska River]. 1995. Zespół Rzeczoznawców Stowarzyszenia Inżynierów i Techników Wodnych i Melioracyjnych, Terenowa Grupa Rzeczoznawców. Rzeszów, maszynopis.

CABALA B., 2001: Ekspertyza wraz z opinią naukową na temat pracy zbiornika wodnego Chańcza czasie lipcowego wezbrania powodziowego $2001 \mathrm{r}$. [The assessment together with scientific opinion on the subject of the work of the water reservoir Chańcza during the flood on July 2001]. Hydroprojekt Warszawa Sp. z o.o., Warszawa. 
CEDERWALL K. 2005: Flood Risks and Dam Safety Interactions. Risk Mapping and Learning from Accidents as a basis for Safety in Spatial Planning Workshop, Karlskrona, Sweden, 154-171.

HEC-RAS, 1997: Hydraulic Reference Manual, ver. 2.0, US Army Corps of Engineers.

HEC-RasSim reservoir system simulation, 2003. US Army Corps of Engineers (USACE). Hydrologic Engineering Center, Davis, California.

KONDRACKI J. 1998: Geografia regionalna Polski [The regional geography of Poland]. PWN. Warszawa.

KRON W. 2002: Keynot lecture: Flood risk= hazard $\times$ exposure $\times$ vulnerability. Flood Defence. Scenie Press, New York Ltd., ISDN 1-880132-54-0, 82-97.

KUBRAK J., NACHLIK E. 2003: Hydrauliczne podstawy obliczania przepustowości koryt rzecznych [The hydraulic fundamentals of calculation of the conveyance of river channels]. Wydawnictwo SGGW, Warszawa

MADEYSKI M. 2006. Efficiency of antiflow effect of a water reservoir. Zesz. Nauk. AR Wrocław, nr 534, p. 211-220.

MICHALEC B., TARNAWSKI M. 2006: Assessment of water conditions of bridges on the Czarna Staszowska river under conditions of water discharge from the Chańcza reservoir. Zesz. Nauk. AR Wrocław nr 534, p. 229-240.

MIKULSKI Z. 1998: Gospodarka Wodna [Water Management]. PWN, Warsaw.

MUTZ M. 2003: The ecology and management of water in world reservoirs. American Fisheries Society Symposium 37, 93-107.

Obliczenie wartości przepływów maksymalnych o prawdopodobieństwie przewyższenia $\mathrm{p}=1 \%$ dla profilu Staszów na rzece Czarnej Staszowskiej. 2002. IMGW Oddział w Krakowie, Biuro Prognoz Hydrologicznych. Kraków, maszynopis.

RODRIGUES A. S., SANTOS M. A., SANTOS A. D. AND ROCHA F. 2002: Dam Break Flood Emergency
Management System. Journal of Water Resources Management, Volume 16/6, Springer Netherlands, 489-503.

Rozporządzenie Ministra Transportu i Gospodarki Morskiej z dnia 30 maja 2000 r. [Decree of Ministry of Transport and Maritime Economy from the day 30 May 2000]. Dziennik Ustaw 63, poz.735.

Streszczenie: Zagrożenie powodziowe terenów poniżej zapory wodnej $w$ warunkach wystapienia ekstremalnych zjawisk hydrologicznych. $\mathrm{W}$ pracy przeanalizowano przebieg powodzi w lipcu 2001 roku i przejście fali wezbraniowej przez zbiornik wodny Chańcza na rzece Czarna Staszowska. Kulminacja tej fali, wynosząca $418,62 \mathrm{~m}^{3} \cdot \mathrm{s}^{-1}$, była dwukrotnie wyższa od szacowanego przepływu o prawdopodobieństwie $1 \%$, na który był projektowany zbiornik. Gospodarowanie wodą w czasie powodzi wymusiło więc większy niż przewidywano jej zrzut w czasie kulminacji. Celem pracy jest określenie układu zwierciadła wody na terenie poniżej zapory przy maksymalnym zrzucie wody ze zbiornika w czasie powodzi, wynoszącym $122,75 \mathrm{~m}^{3} \cdot \mathrm{s}^{-1}$, oraz wskazanie możliwości zmniejszania zagrożenia powodziowego. Wyznaczono zasięg strefy zatopienia przy tym przepływie zrzutowym na terenie położonym poniżej zapory na długości ponad $3 \mathrm{~km}$, uwzględniając wpływ roślinności w dolinie i strefie przykorytowej oraz mostu. Przyczyną zatopienia doliny na badanym odcinku rzeki jest niewielka przepustowość koryta wynosząca zaledwie od $12,0 \mathrm{~m}^{3} \cdot \mathrm{s}^{-1}$ do $62,8 \mathrm{~m}^{3} \cdot \mathrm{s}^{-1}$. Stwierdzono, że most nie wpływa na spiętrzenie analizowanego przepływu, a zapas w świetle mostu, określony jako różnica rzędnej spągu belki przęsła i rzędnej zwierciadła wody w moście, wynosi ponad $0,9 \mathrm{~m}$. Wykonano również obliczenia przepustowości koryta, w przypadku wykonania zabiegów konserwacyjnych polegających na usunięciu roślinności sztywnej i miękkiej, wykazano zmniejszenie zasięgu zatopienia dna doliny. Zmniejszenie zagrożenia powodziowego terenów położonych poniżej zapory Chańcza może zostać osiagnnięte przez wykonanie zabiegów konserwacyjnych koryta bez zmiany jego geometrii przekroju poprzecznego. Wykonanie zabiegów konserwacyjnych w korycie może nie zostać zrealizowane ze względu na propozycję włączenia badanych tere- 
nów do obszarów chronionych programem Natura 2000. Zachowanie w istniejącym stanie zabudowy roślinnej koryta rzeki Czarna Staszowska poniżej zbiornika, charakteryzującego się niewielką przepustowością, wymusza wprowadzenie zmian do instrukcji eksploatacji zbiornika, polegających na opracowaniu systemu monitoringu hydrometeorologicznego zlewni, prognozy kulminacji fali. $\mathrm{Na}$ tej podstawie możliwe będzie wcześniejsze zwiększenie pojemności powodziowej zbiornika przez przeprowadzenie zrzutów o mniejszym przepływie, niezagrażających zalaniem terenów poniżej zapory.
MS. received May 2009

\author{
Authors' address: \\ Marek Madeyski (zm. 28.04.2009 r.) \\ Bogusław Michalec \\ Marek Tarnawski \\ Department of Water Engineering \\ Agriculture University in Cracow \\ Al. A. Mickiewicza 24/28 \\ 30-059 Cracow \\ e-mail: rmmichbo@cyf-kr.edu.pl \\ e-mail:rmtarnaw@cyf-kr.edu.p
}

